\title{
Artistic autonomy in non-autonomous contexts: reframing collective agency and insurgence from Caribbean artist-managed spaces
}

\section{Carlos Garrido Castellano}

To cite this article: Carlos Garrido Castellano (2017): Artistic autonomy in non-autonomous contexts: reframing collective agency and insurgence from Caribbean artist-managed spaces, Social Identities

To link to this article: http://dx.doi.org/10.1080/13504630.2017.1303370

曲 Published online: 17 Mar 2017.

Submit your article to this journal $\widetilde{ }$

Q View related articles $\sqsubset$

View Crossmark data $\complement$ 


\section{Artistic autonomy in non-autonomous contexts: reframing collective agency and insurgence from Caribbean artist-managed spaces}

\section{Carlos Garrido Castellano}

Comparative Studies Center, University of Lisbon, Faculdade de Letras, Alameda da Universidade, Lisbon, Portugal

\begin{abstract}
This article engages the debates on collective agency, autonomy, institutional practices and socially engaged art by comparatively analyzing the activity of two Caribbean artist-managed spaces which emerged in the first decade of the twenty-first century: BetaLocal in Puerto Rico and L'Artocarpe in Guadeloupe. Based on fieldwork research and interviews with artists and art audiences, the examination of both projects will be driven by three main objectives: the first has to do with assessing in which ways both initiatives are shaped by their emergence in territories still attached to political and economic bonds. Secondly, I attempt to measure how both collective artistic organizations can approach the material conditions of cultural (re)production and autonomy, confronting the restrictions of Puerto Rican and Guadeloupean cultural and economic policies. Finally, I intend to locate my case study within a global panorama of socially engaged and collaborative artistic practice. From this perspective, I assert that collaborative practices emerging in still dependent contexts constitute a privileged viewpoint in order to examine issues of collective agency, empowerment and alternative futures.
\end{abstract}

ARTICLE HISTORY

Received 18 August 2016

Accepted 27 February 2017

\section{KEYWORDS}

Artist-managed spaces; autonomy; Caribbean; collective agency socially engaged art

The recent interest in analyzing and historicizing Caribbean artistic practices is not without its blind spots. Especially blatant in this regard is the attention that infrastructural and organizational initiatives have received. There is a striking lack of attention being paid to artistic projects attempting to define non-commercial, collective modes of creativity. Instead, much more attention has been paid at how the region has been rendered exotic, labeled and commoditized. ${ }^{1}$ Whoever approaches the histories of contemporary Caribbean visual creativity will find an individual register, made up of singularized names, issues and causes. The fact that many of these artists frequently arise from and develop their careers through collaborative, artist-managed platforms is mentioned with less frequency. Something similar happens with the role of Caribbean creators in redefining cultural and social agency in local contexts. The practical situation of many of the artists living in the region, and somehow of many 'local' art scenes, is somehow neglected 
by the favorable analysis of the transformative qualities of individual aesthetic discourses (Figures 1-9).

I will not aim to overturn this critical tradition. Instead, this text pursues a far more modest and focused objective: to see how artistic collaboration works in, and responds to, Caribbean contexts still subjected to political and economic bonds with their former metropolis. ${ }^{2}$ In order to do so, I will comparatively examine the activity of BetaLocal, a Puerto Rican artist-managed space, and L'Artocarpe, the first collaborative initiative arising in the Francophone archipelago of Guadeloupe. Puerto Rico is an Associated Free State (Estado Libre Asociado) of the United States since 1952. Guadeloupe is a French 'Département d'Outre Mer' since 1946. The cultural milieu of both contexts is profoundly affected by this condition of political, administrative and economic dependence. The metropolitan territories still determine what are the models to be followed, the venues where art should be exhibited, which projects are funded and under what conditions, the colleges and art schools that artists are supposed to join, etcetera. Both BetaLocal and L'Artocarpe emerge out of this predicament, but they also stand as critical responses to it. Created in the 2000s, both projects share many elements: they rely on horizontal and flexible organizational structures; they go beyond representational and individual conceptualizations of artistic practice; they agglutinate heterogeneous, 'unusual' audiences; they carry out extra-artistic functions; they, finally, operate locally while also countering a dependency toward metropolitan territories. Those elements constitute, I will argue, an interesting cultural model for two particular reasons: first, they challenge the image of the Caribbean as provider of 'creative raw material', of individual discourses and artworks that need a foreign hand to be articulated under more complex curatorial or institutional agendas; second, they attempt to subvert the dependency of both Puerto Rico and Guadeloupe by generating critical cultural dynamics. To be sure, alternative spaces and

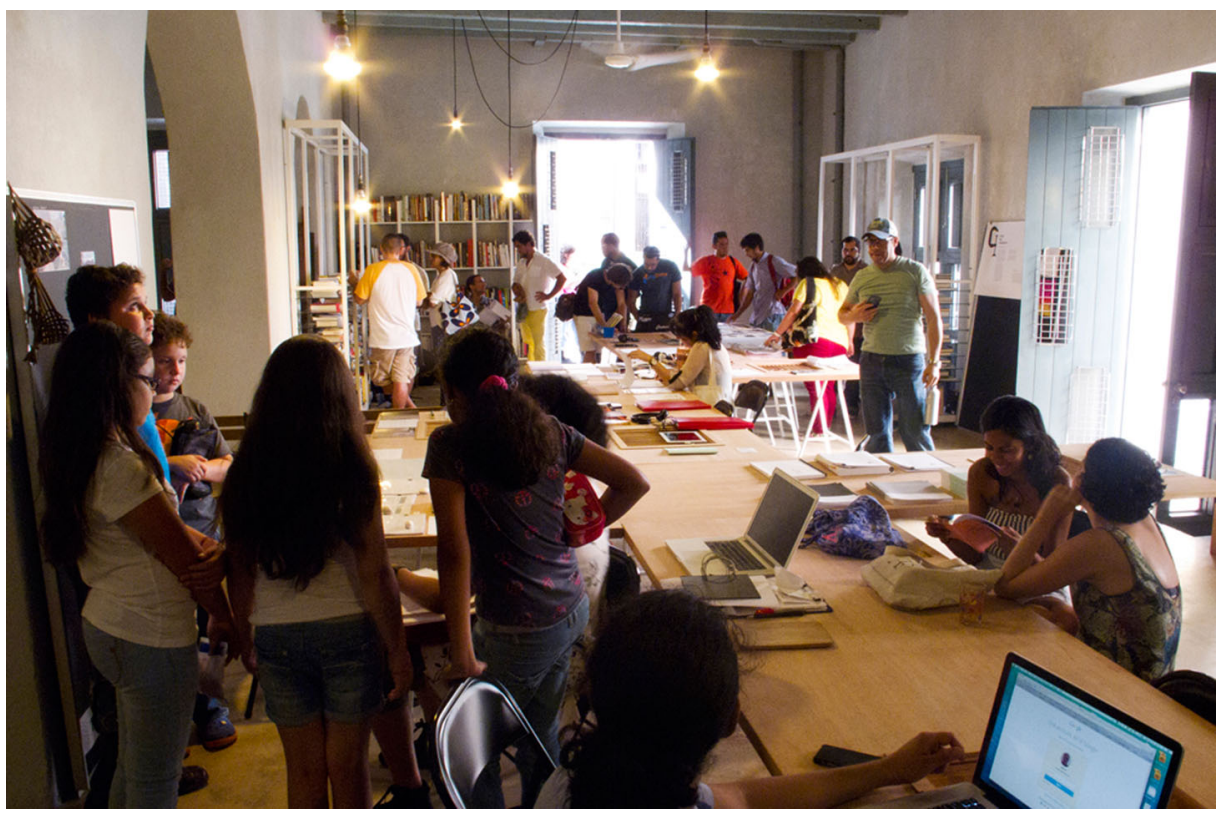

Figure 1. BetaLocal. La Práctica Program. 2012. Image Courtesy of Beatriz Santiago Muñoz. 


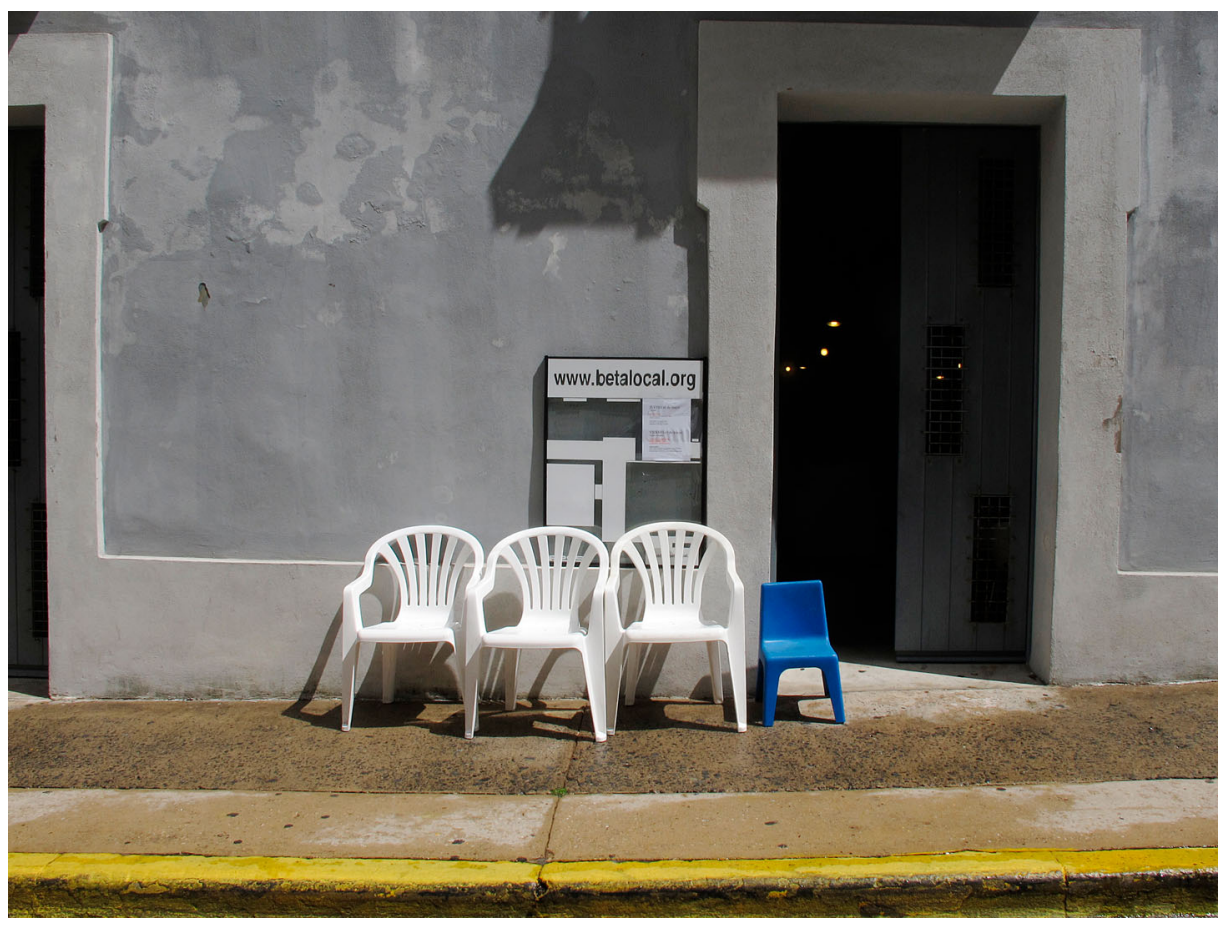

Figure 2. BetaLocal-Old San Juan (Puerto Rico). Image Courtesy of Beatriz Santiago Muñoz.

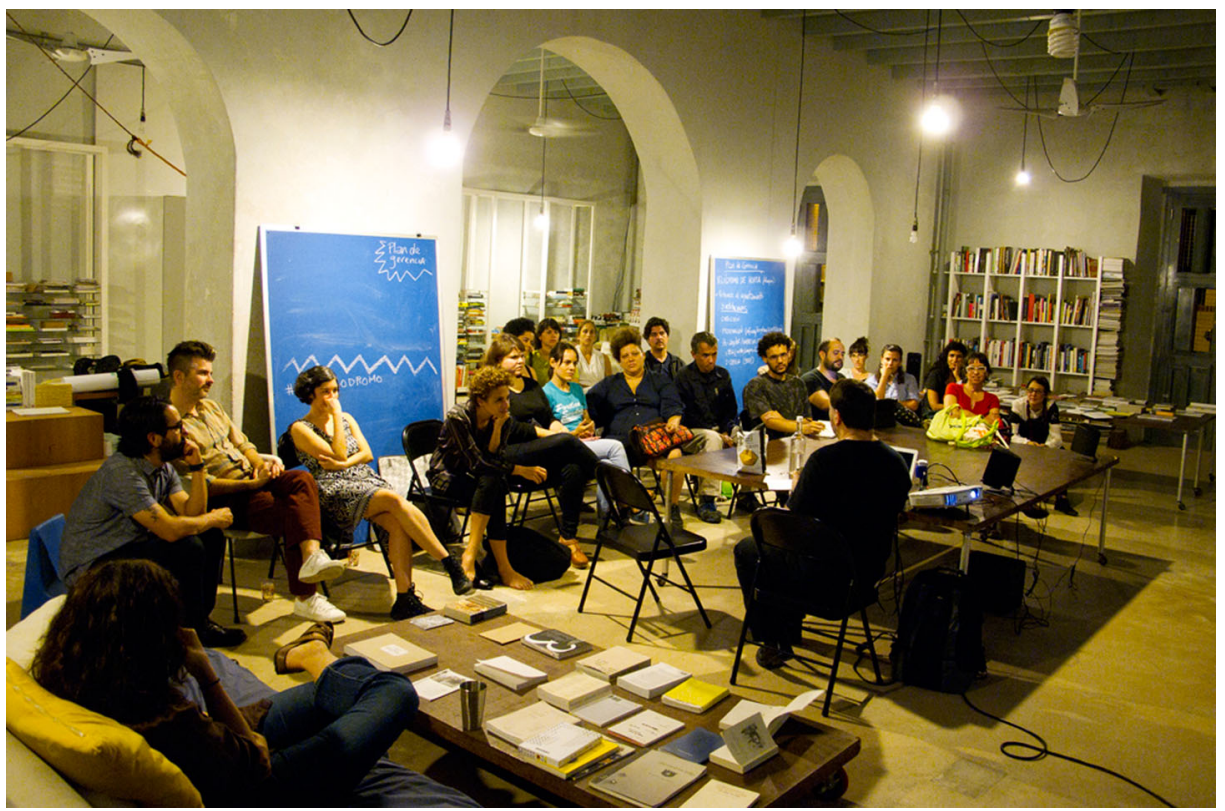

Figure 3. BetaLocal. Workshop on Cultural Management. 2011. Image Courtesy of Beatriz Santiago Muñoz. 


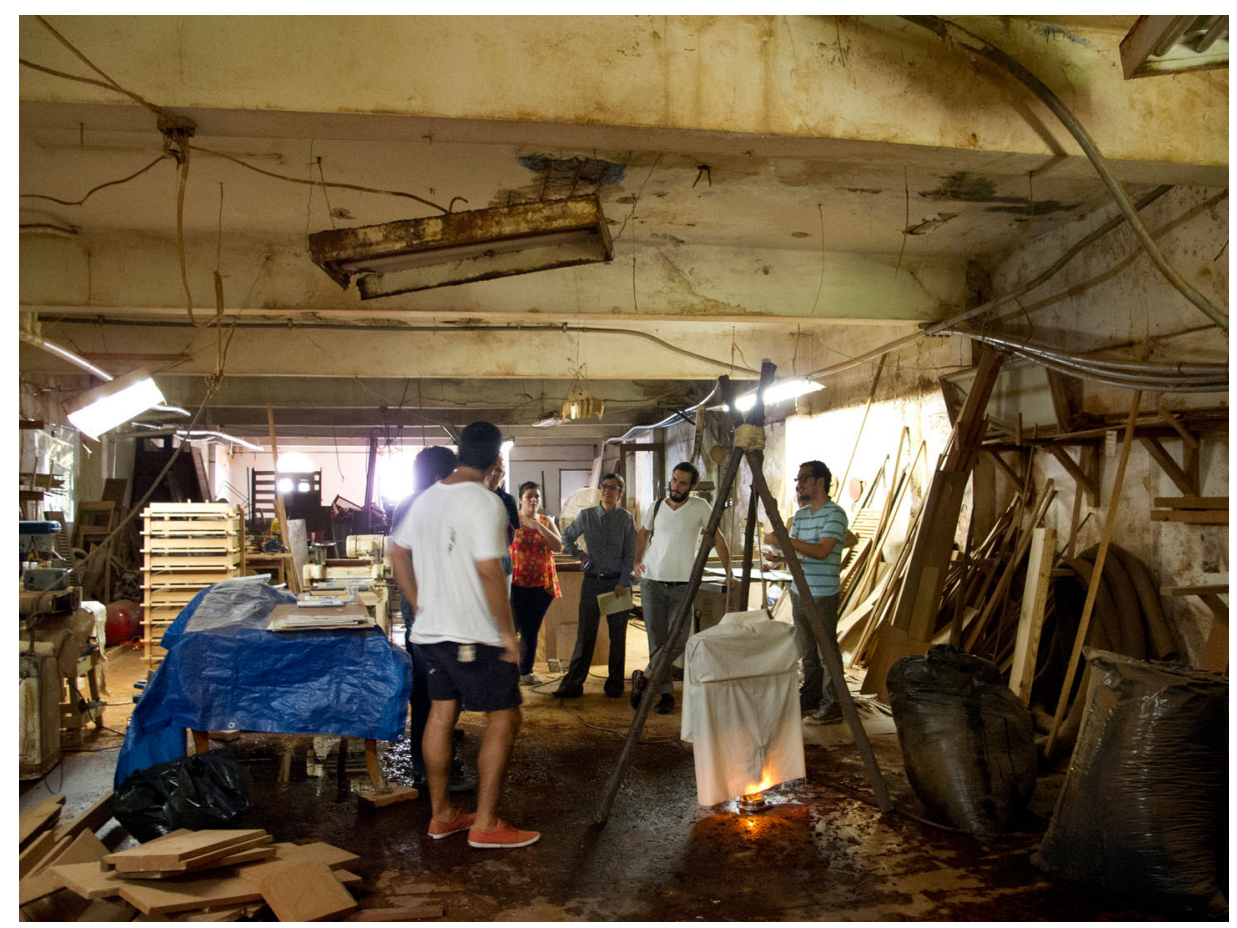

Figure 4. BetaLocal. Outdoor Project. 2011. Image Courtesy of Beatriz Santiago Muñoz.

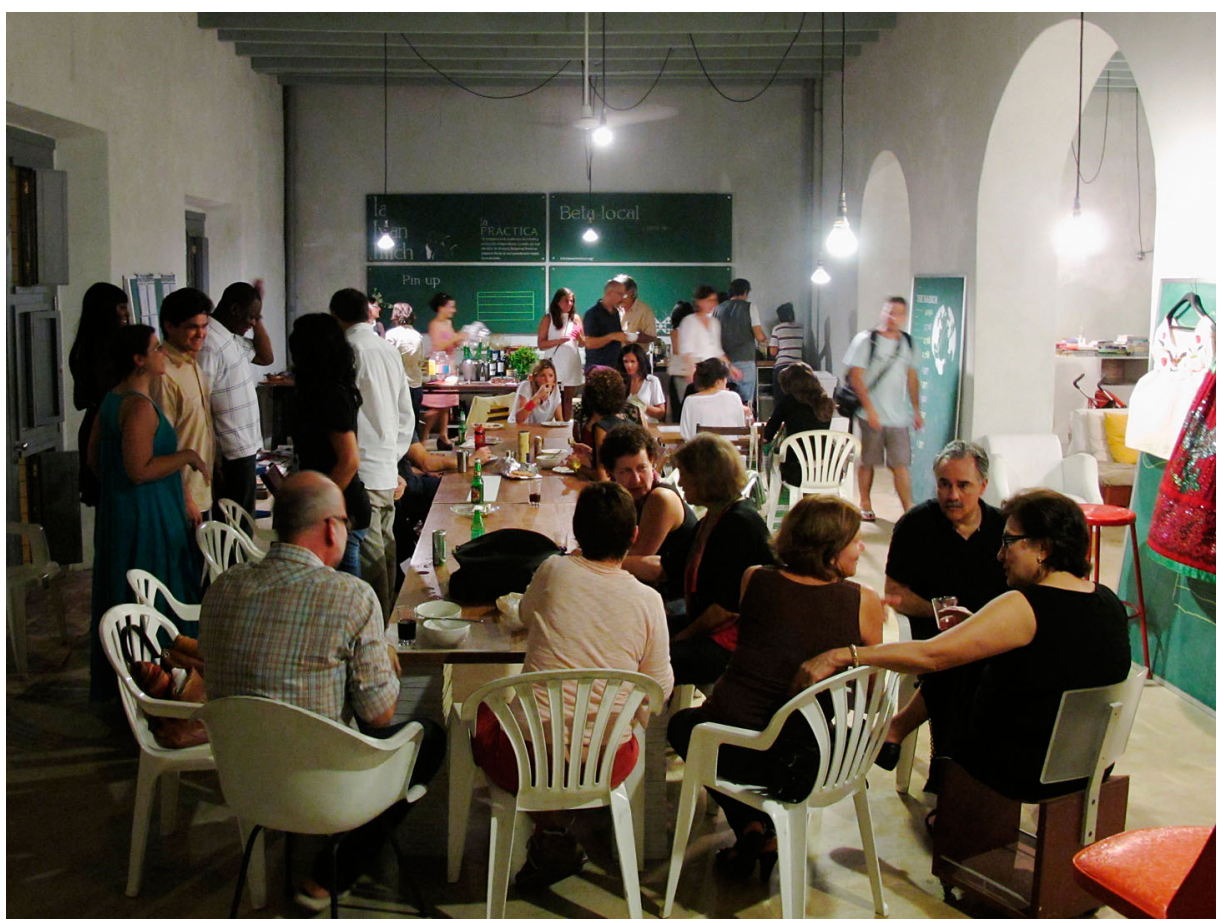

Figure 5. BetaLocal. Potluck. Image Courtesy of Beatriz Santiago Muñoz. 


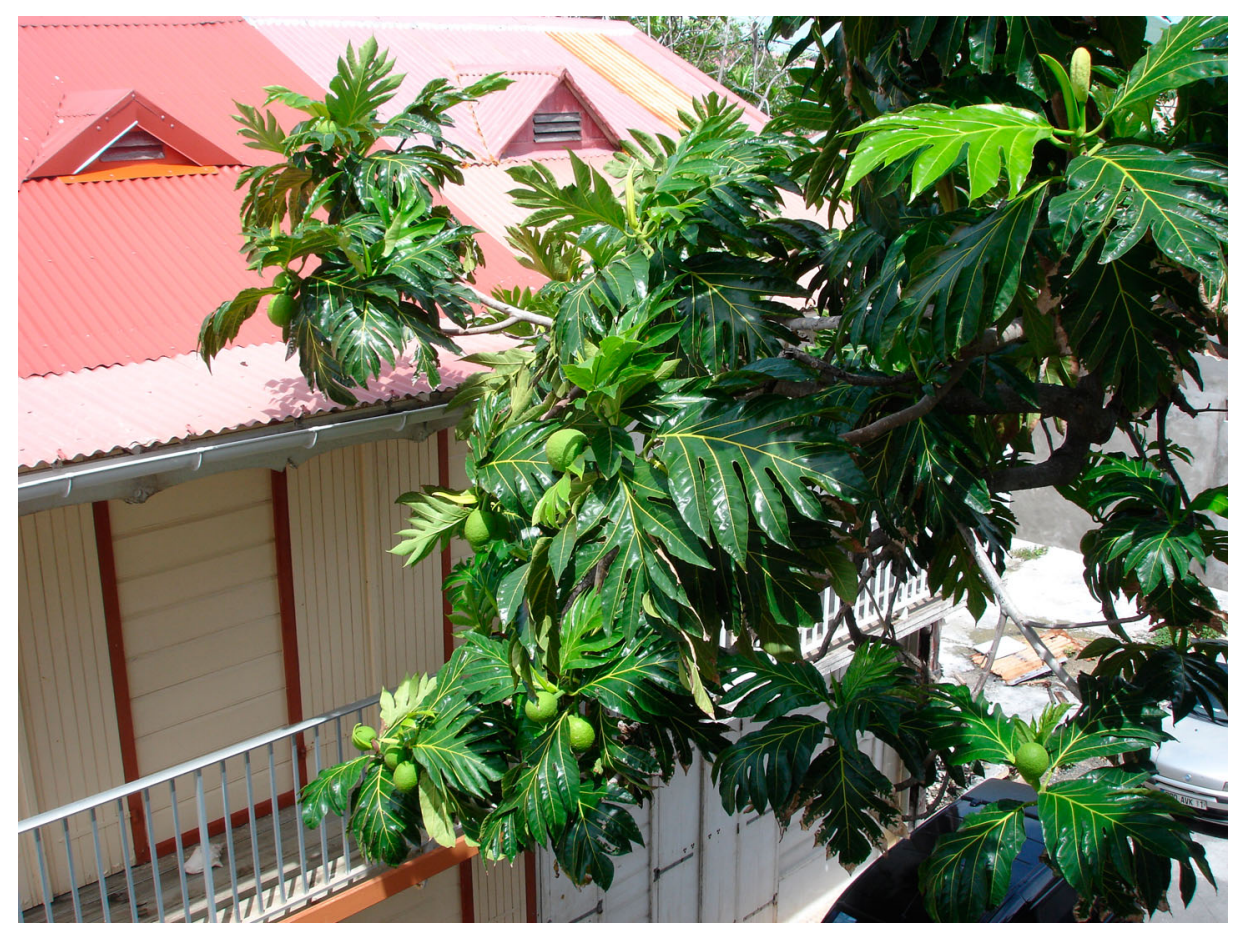

Figure 6. L'Artocarpe-Detail of the Bread Fruit Tree after which the space is named. Image: The author of this article.

collaborative practices are very much present in any artistic genealogy, being a usual suspect in many contemporary artistic contexts. Kester (2011, p. 5) has linked the success of artistic collaboration with the rise of a powerful neoliberal economic order dedicated to eliminating all forms of collective or public resistance (institutional, ideological and organizational) to the primacy of capital'. This landscape would appear familiar to anyone working in the cultural milieu notwithstanding of her location. Having said that, I also believe that nor the obstacles deriving from that situation, nor the responses to it, constitute a homogeneous panorama. By paying attention at how collaboration and alternative institutionalism are put into practice in two contexts strongly influenced by its colonial situation, in this article I attempt to show how both BetaLocal and L'Artocarpe offer a vantage point from which the analysis of emergent infrastructural practices can be framed.

Two main objectives will center my analysis. The first one focuses on assessing the specific in collaborative, infrastructural projects taking place within territories still bound by relationships of dependency. Are we to imagine those as an exception in an otherwise seemingly homogeneous global social imagination marked by neoliberal economic and social currents? Is there anything unique to these projects, in a moment supposedly marked by the forces of increasingly de-territorialized and transnational phenomena? In other words, if collectivism is associated with autonomy, organizational capacity and collective agency, what relevance can we concede to the 'non-autonomous locality' in which our case studies operate? In which way will that locality determine and constrain the expectations and agendas of these projects? And finally, if we are to recognize some 


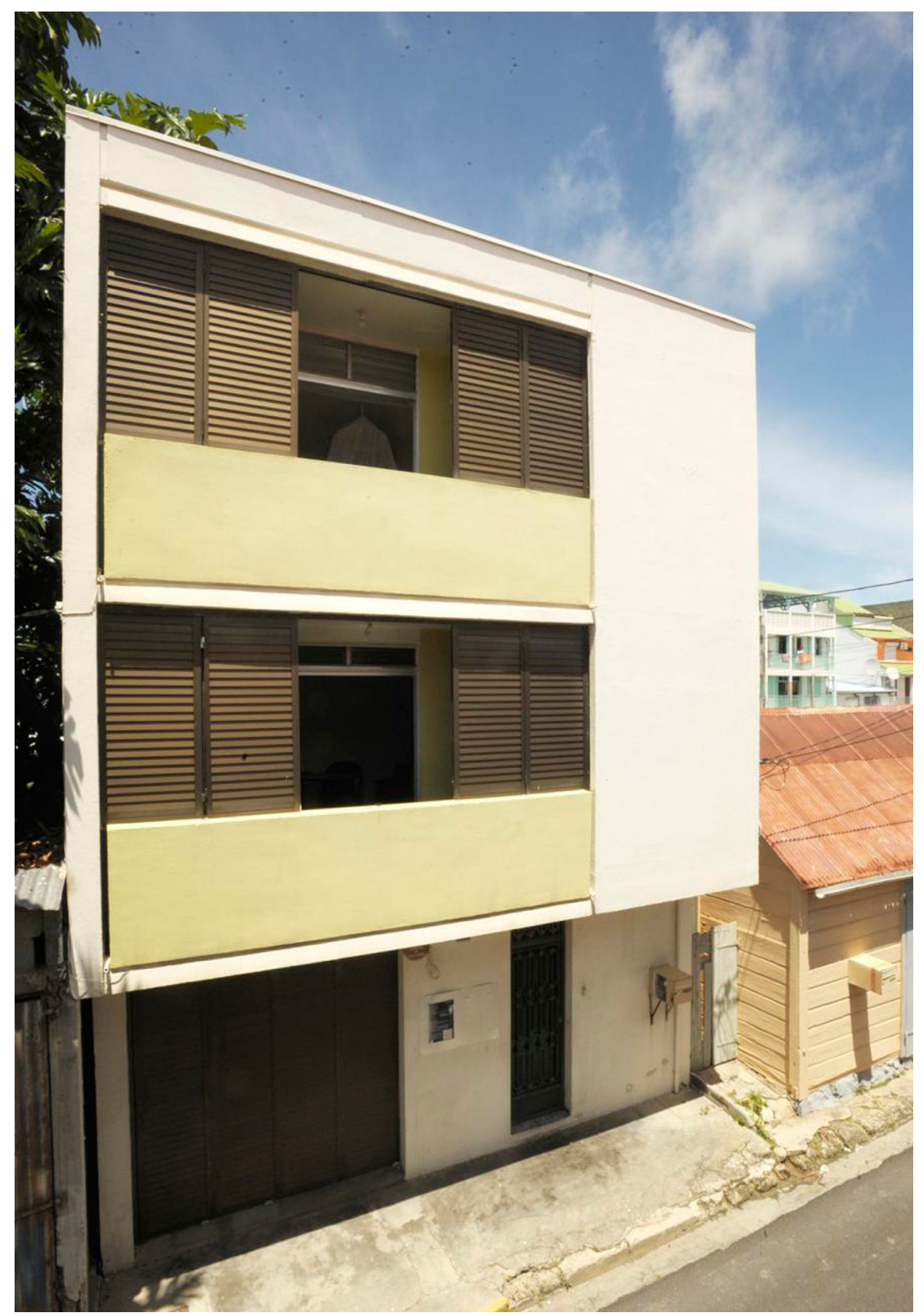

Figure 7. L'Artocarpe-Le Moule (Guadeloupe). Image Courtesy of Joëlle Ferly.

inherent singularity in these projects, what are the contributions of L'Artocarpe and Betalocal to the present global narratives and the potentialities of (artistic) collaboration? Secondly, I will seek to examine how both projects engage active, transformative actions, thereby enabling alternative institutional practices. If we are to recognize an emergent, transformative potential in (certain) collective art practices, it will be necessary to 


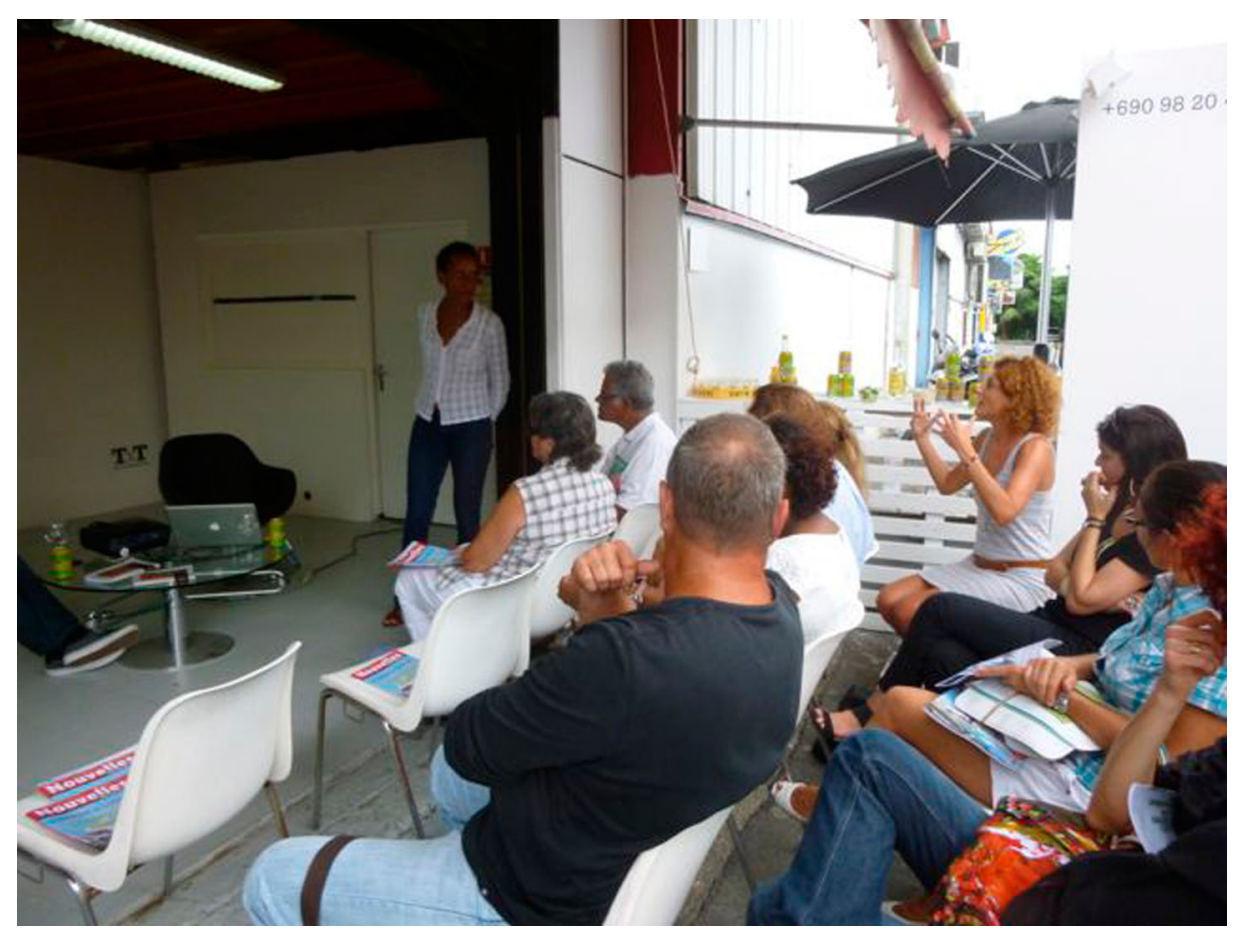

Figure 8. L'Artocarpe. Group Conversation with resident Fabienne Viala. 2014. Image Courtesy of Joëlle Ferly.

measure to what extent this potential can be captured by the institutional logic present in Puerto Rico and Guadeloupe. Before that, I will introduce briefly the history of infrastructural and collective artistic creativity in the Caribbean in which my two projects are inserted.

\section{Infrastructural and collective artistic agency in the Caribbean}

Although the emergence of BetaLocal and L'Artocarpe can be linked to the effervescence of organizational, politically engaged and infrastructural practices across the world and specially in the Americas (see Craven, 2006; Mosquera, 1996; Thompson, 2012), they also continue a long tradition of socially engaged art present in both countries. In the case of Puerto Rico, we can recall a long tradition of alternative spaces starting already in the 60s with Antonio Martorell's Taller Alacrán, ${ }^{3}$ and consolidating in the $70 \mathrm{~s}$ and $80 \mathrm{~s}$ through artist-driven initiatives such as Casa Aboy, the Liga de Estudiantes de Arte, Casa Candina, MSA or the actual Museo de Arte Contemporáneo de Puerto Rico (MAC), located since 2002 in Casa Labra. Puerto Rican alternative spaces and socially driven projects will gain momentum in the 2000s, in a context of political and economic instability. The actions of Chemi Rosado Seijo in El Cerro, perhaps one of the most internationally acclaimed initiatives, will prelude the burst of alternative spaces and projects that will mark the decade, among them Área, =Desto, 787, Car Watch, Metro, Clandestino787, Conboca or The Status (see Segarra, 2012). The impact of those projects in the definition of a public sphere in Puerto Rico has been crucial: many of them have striven to survive in 


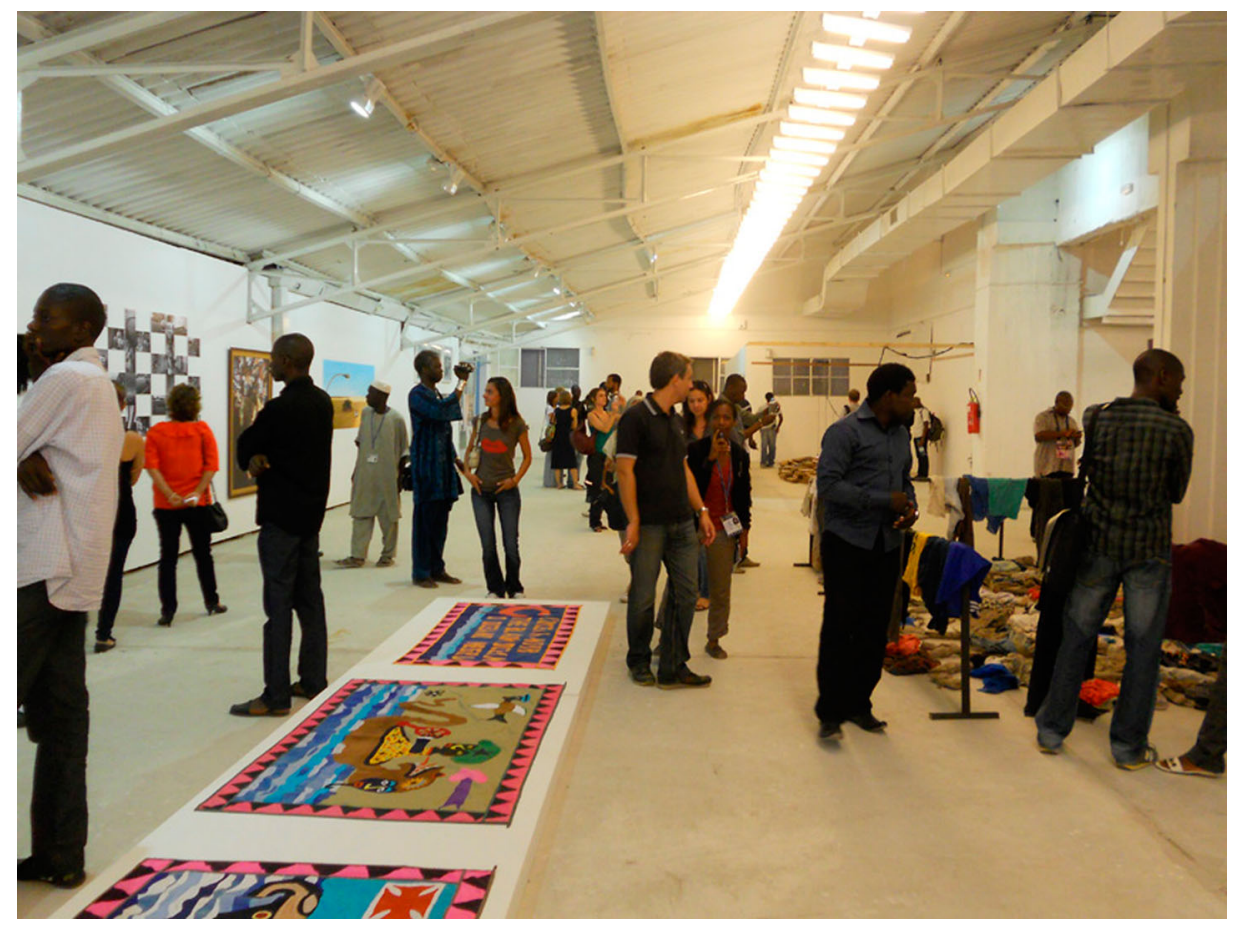

Figure 9. Participation of a Group of Guadeloupean Artists at FESMAN, Dakar, 2011. Image courtesy of Joëlle Ferly.

the years of the debt crisis, providing artists a space for affirmation, debate and creativity. It comes with no surprise that they have engaged actively most of the political and economic causes the country has gone through in the last decade, from the conflict of sovereignty in Vieques Island to the strikes against the privatization of university education in the late 2000s.

In the case of the Francophone Caribbean, we can also mention artistic collectives seeking to transcend the colonial heritage and the dependence toward the French metropolis. The École Negro-Caraïbe, founded in 1970 by the painter Louis Lauchez and the sculptor Serge Hélénon, attempted to challenge the influence of academic artistic education and the hegemony of an unproblematic and stereotyped vision of the Caribbean tropical landscape. Driven by a Pan Africanist ideology, L'École sought to reinforce the link between the Francophone Caribbean and Africa (see Fall \& Pivin, 2002; L'Étang, 2007). Later on, in the 80s, the collective Fwomajé will focus on defining a militant vision of creolité, attempting to insert artistic practice within the local insular reality (Tiburce, 1994).

This tradition, moreover, is not a prerogative of Puerto Rico or Guadelopue. Initiatives like CCA7, Alice Yard and Galvanize in Trinidad ${ }^{4}$; Fresh Milk in Barbados ${ }^{5}$; LASA, Espacio Aglutinador, the Cátedra de Arte y Conducta or DUPP in $\mathrm{Cuba}^{6}$ or the Instituto Buena Bista in Curação, ${ }^{7}$ to name just a few, have been key in promoting alternative approaches to creativity and in incardinating non-artistic audiences in cultural processes. They have also promoted artistic mobility within the region. Through long-term actions, they have opened up a space for discussion and organization, countering the dynamic of market 
and prestige-driven platforms. Something similar can be said of transnational initiatives such as Tilting Axis, ARC or Small Axe, which function as platforms encouraging artistic dialogue, exchange and collaboration.

\section{BetaLocal}

BetaLocal was created in 2005 by Puerto Rican cultural entrepreneur Michelle Marxuach and artists Beatriz Santiago and José 'Tony' Cruz. They refurbished a single-floor building owned by Marxuach in Old San Juan to serve as an art residency, exhibition space and meeting point. For this purpose, they used the network created in previous years through the organization of ' $M \& M$ ', a biennial event funded by Marxuach. M\&M brought to Puerto Rico a wide range of top-tier artists and curators (including Rirkrit Tiravanija, Hou Hanru, Adel Abdessemed), and have exhibited the work of Linda Montano, Gilbert and George, Marina Abramovic and Vito Acconci. After the third edition of M\&M, the project was dissolved and transformed into BetaLocal. Unlike 'M\&M,' since its beginnings, BetaLocal has aimed to engage with non-artistic audiences, confronting political causes and fulfilling specific social and cultural needs. ${ }^{8}$ Its temporal operation has also differed from the more periodical biennial system. The reason for this change lay in the constraints they found while organizing the M\&M biennials. Although these were organized as a private initiative, exempt of the need to represent any single country or institution, they relied on the 'traditional' scheme of biennials, intending to 'insert' local creators within an internationalized art scene and to bring to Puerto Rico internationally renowned artists and audiences.

BetaLocal has sought to personify a different model. Initially conceived as an alternative library and archival space that was open to all, it soon evolved in order to integrate other features and programs. Among those, the first organized was 'La Práctica' [The Practice], an immersive collective research program open to artists, researchers and cultural activists. The program, defined as a 'horizontal, peer-taught' experience (personal communication with José 'Tony' Cruz, Beatriz Santiago and Pablo Guardiola, March 2015), consisted of the annual selection of up to five people with the aim of developing cooperative practical, onsite research, while also collaborating with all the other initiatives fostered by BetaLocal. La Práctica offers a residency space and encourages the fellowship recipients to devote a number of hours per week to collaborate with different artistic and non-artistic communities. These collaborations result in ongoing joint research initiatives, talks and reading sessions. Under this scheme, the invited persons are not considered 'specialists'; rather, they are specifically sought out in response to the requests made by the various groups who regularly visit BetaLocal. What is important is that all the people who are involved in these actions participate in equal terms in the research process, with the results aimed at addressing and responding to collective expectations and desires. Residents are therefore compelled to decentralize their own positions and transform their original ideas into cooperative productive action. ${ }^{9}$

The second initiative that was developed chronologically was 'La Ivan Illich,' which expands and extrapolates to Puerto Rico the model of The Public School. ${ }^{10}$ Conceived as a 'de-educating', curriculum-free educational experience, the program asks anyone who is interested to propose a particular lesson which she or he wants to receive or teach. BetaLocal provides the space for those exchanges to take place and seeks to 
satisfy the requests that are received. Finally, 'The Harbor' represents the most conventional long-lasting initiative developed by BetaLocal, functioning as a more traditional art residency for international guests.

BetaLocal's organizational model can be explained by alluding to three interrelated ideas: flexibility, authority and horizontality. Each program has its own guiding principles and is directed toward different audiences. They may integrate non-artistic sectors, experienced artists and/or curators alike. This approach seeks to counter the isolation of artistic practice from social imagination. Whereas 'alternative' cultural events abound in the Puerto Rican cultural landscape, in many occasions they are directed toward a limited 'art-educated' audience. By diversifying their initiatives and making them more flexible, BetaLocal aims to transcend this situation, although, as the project's founders have stated, this has not always been achieved. ${ }^{11}$ What sets BetaLocal apart is, in any event, the combination of flexibility with a direct challenge to specialization-based authority and hierarchical organization.

\section{L'Artocarpe}

L'Artocarpe opened in 2009 as the first artist-managed institution in Guadeloupe. Founded by Joëlle Ferly, a Guadeloupean artist trained in London and Paris, L'Artocarpe seeks to counter a predicament of institutional non-existence and social isolation which diminish social interaction and prioritize production and commoditization in detriment to discussion and exchange. Located in the municipality of Le Moule, L'Artocarpe has sought to define itself as a trade-union-like structure geared more toward production, experimentation and dialogue than exhibition. Its structure consists of a federation of members, most of them artists, who are allowed to use the space for developing their work and for exchanging impressions. L'Artocarpe is also an art residency that encourages international visitors to interact with local creators through a range of activities that include open discussions, workshops and studio visits. Visitors are not committed to transform their stay into a perfectly finished product, such as an exhibition. Rather, they are invited to use the space and the structure of L'Artocarpe to advance in-progress projects and to conduct practical research. These initiatives seek to connect the community of Guadeloupean artists with other territories besides France, thereby loosening the dependence toward the metropolitan space and its art scene. The geographical distribution of the interns is eloquent in this regard: artists and academics from the Dominican Republic, Saint Martin, Puerto Rico, Trinidad, Haiti, England and the Netherlands have stayed for extended periods in Le Moule. This constitutes a major transformation in the cultural life of a town of approximately 23,000 inhabitants. In this sense, by positioning itself at the side of process-oriented, long-term creativity, the residency allows constant feedback and international exchange despite the cultural oblivion motivated by the organizational distribution of the Caribbean Départements d'Outre Mer [French Overseas Departments] or DOMs that I will analyze further on.

Besides operating as a place for artistic production and art residency, the third function of L'Artocarpe is directed toward the local community. It intends to improve the visibility of Guadeloupean art abroad. Whereas Caribbean art has been exhibited worldwide within the last two decades, there has been a disparity with regard to the participation of some territories. The Lesser Antilles have, by and large, been underrepresented in large- 
scale exhibitions and cultural initiatives both within and outside the region (see Bailey, Cummins, Lapp, \& Thompson, 2012; Cullen \& Fuentes, 2012). Many reasons can explain this situation: some of which can be easily summarized by alluding to the size disproportion between the islands or to the historical development of cultural institutions in the Spanish-speaking Caribbean. These 'official,' historical structures are to a large degree still lacking in many Caribbean territories. It was not until the last years of the twentieth century that some artists began to be included more regularly in regional and international circuits. Since its foundation, L'Artocarpe has managed and accompanied projects of Guadeloupean artists for international events such as the World Festival of Black Arts (FESMAN) in Dakar and the Havana Biennial, thus including Guadeloupeans in those forums for the first time. This factor is especially relevant for three reasons: first, it counters the cultural isolation of Guadeloupe both regionally and internationally; second, it provides Guadeloupean artists with an artistic experience that they otherwise would not have due to the lack of local infrastructures for those purposes ${ }^{12}$; and, finally, it deals with an institutional and political vacuum that concerns not only art - in 2014, L'Artocarpe managed to convince the French Embassy in Cuba to fund the participation of the Guadeloupean Henry Tauliaut alongside metropolitan French artists represented in the 2015 edition of the Havana Biennial.

\section{Strategy, artistic labor and education}

It is precisely because collectivism brings focus to - inevitably, uniquely - the broader social and economic conditions of production, which are themselves always collective despite appearance, that it is capable of returning again and again to haunt both past and present. (Stimson \& Sholette, 2007, pp. 10-11)

A major first point of convergence between my two examples arises from how they address the dependent predicament of Puerto Rico and Guadeloupe and its impact on what it means to be an artist. The artistic infrastructures of both territories are conditioned by some similar elements (which are, we should not forget, not exclusive of those two contexts): among them, the primacy of individual success over collaborative structures; an impossibility of full acknowledgment, and a permanence of exclusion on the part of the metropolitan powers to which they are bound; and the orientation of artistic practice toward 'niche' and marketable ends. Some of these features, it can be argued, are prerogatives of a more general, neoliberal turn in 'the art world'. Others are clearly specific to the dependent status of both territories, however. This panorama can be summarized by alluding to three influential elements: the dependence of cultural infrastructures on US and French financial sources; a Western expectation of difference and exoticism that has regulated the commoditization of Caribbean artistic practice, imposing external notions of modernity, expertise and success, and forcing artists to respond to foreign needs and expectations (see Cozier, 2011); and a unstructured or deregulated institutional framework, in which several public functions are either cast aside or carried out by nonpublic agents.

In two radically different ways, both BetaLocal and L'Artocarpe aim to challenge the predicaments I have outlined above. In the first case, this becomes materialized, above all, in the form of de-specialization and alternative education. La Iván Illich, the deregulated public educational program, is a good example of that, and I will focus on it now. 
This program accomplishes a range of functions. First, it challenges the image of autonomy fostered by the Puerto Rican artistic infrastructure. The program reveals how some needs are being covered neither by public institutions nor by private, market-oriented agendas. One of the most vibrant in the entire Caribbean, the Puerto Rican artistic milieu presents a rich institutional landscape, with several contemporary art museums, art centers and universities offering graduate and postgraduate degrees in fine arts. In San Juan alone, we find three large-scale contemporary art museums, which have also proven to be particularly active in engaging with local communities. ${ }^{13}$ Despite this institutional abundance, the artistic infrastructure is seriously limited by economic restraints and a lack of opportunities. Whereas it is easy to find places to exhibit, it is difficult to develop a successful career from artistic production. In order to do that, Puerto Rican artists need to migrate to the United States and to join graduate or postgraduate courses. The return after completing those courses is equally difficult, being that predicament highly present in the Puerto Rican diasporic imaginary (see Flores, 2010). Moreover, the art scene is somehow only accessible for reduced audiences. This also applies to the case of artist-managed structures, including BetaLocal. Finally, the programs of support for the arts are intermittent and always depend on the political situation.

Another key function of the initiative has to do with operating as a backdoor into which many individuals not interested in contemporary art, or not belonging to the 'art audience,' enter the artistic space and interact with other initiatives. BetaLocal's directors emphasize the importance of the project as a 'way in', that is, as a tool for bringing together heterogeneous audiences: 'There are people who appropriate the space in different ways. Some stay and join other activities; some others don't.. ${ }^{14}$ Since many of the lessons take place in other locations outside the BetaLocal space, in those places where the demand is articulated, La Iván Illich serves as the project's main decentralizing tool.

It is significant that La Iván Illich does not oppose other educational models; rather, it attempts to complement their lacunae. In fact, oppositionality is the antithesis of the initiative's main objectives. It does not attempt so much to fully reject artistic expertise, as to appropriate it as part of BetaLocal's tactical repertoire. Something similar can be said concerning the 'undoing' of the Puerto Rican non-autonomous condition. Although the program does not address it directly, it does address the social conditions, the deficiencies, the desires, the anxieties and the margins of artistic practice within the island. However, the project cannot be seen as a 'relational space' free of conflict, a neutral scenario for exchanges. Being an exercise of social imagination, it is more reflective of situations of exclusion and lack of communication than with the unlimited exchange outlined by the theoretician of relational aesthetics (Bourriaud, 2002, p. 14). For Bourriaud (2002, pp. 15-16), the development of modern cities and the fluxes of globalization generated 'the experience of proximity', which would lead him to consider artworks and art exhibitions as 'social interstices'.

Many things distance the activity of BetaLocal, and particularly La Iván Illich, from those interstices. Whereas Bourriaud's model is based on the (more innocuous) temporality and spatiality of the exhibition space, in our case we find a structure seeking to expand beyond 'artistic spaces'. In order to achieve this, initiatives such as La Iván Illich appropriate and overlap the 'communication zones' and resources that are locally available. This imbues the project with a contingent condition, one that is dependent on specific needs of specific groups and communities. Indeed, the initiative's main concern is not with 
generating aesthetic exchanges and 'durational experiences'; rather it is about exposing and countering the misunderstandings and deficiencies generated by the Puerto Rican cultural and academic infrastructures. These aspects are part of BetaLocal's active, generative role.

Let us move now to L'Artocarpe, which operates in a far different landscape. The Guadeloupean archipelago lacked the most basic institutional structures for the development of artistic production, despite the fact that artistic production susceptible to being defined as 'contemporary' has existed since the 1950s. The reason for this is intrinsically related to the organizational scheme of the DOMs. The territories of French Guiana, Guadeloupe and Martinique are highly centralized, with Martinique functioning as the main cultural center. It is common for many students and art practitioners to move either to Fort-de-France or to the metropolis to develop their careers. In any event, even in Martinique artistic practice is oriented toward production and display. What prevails is a disseminated landscape in which artists living in the region have their own workplace in their homes and focus on their own production in order to then participate in the French art market or collective art exhibitions abroad. Production, furthermore, has to cope largely with the expectations of the metropolitan scene, which materializes in many cases in the creation of a niche of 'Other art' that is rarely positioned equally alongside French production. ${ }^{15}$ 'Contemporary artists', nevertheless, only represent a minimal percentage of the region's artistic population, with a much larger number of amateur painters devoted to satisfying the needs of the visiting tourists. These difficulties are further compounded in French Guiana and Guadeloupe. $^{16}$

The union-like structure of L'Artocarpe can be seen as the project's main engagement with artistic labor and its main response to this scenario. The benefits L'Artocarpe provide to its 'federation' of artists are directly related to the aforementioned isolation and marketoriented individualism. The project has served as a platform for cooperation and social interaction. It provides a meeting point for them, acting as an open space that can be occupied by several activities. Indeed, L'Artocarpe's agenda seeks to emulate the original significance of the tree from which the initiative derives its name. A huge Artocarpus (breadfruit tree) is planted right beside the art building. As its director states, the choice of an arboreal location bears not only a powerful symbolic charge, but also endeavors to root the social struggles over citizenship, cooperation and collective agency within a liberating agenda that can be traced back to the plantation society:

Bread fruit trees have historical bearing: their fruits were eaten by running slaves escaping bondage. Today, the trees continue to feed poor families and artists who are struggling with the high costs of living on an island under the growing influence of French monopoly and [neo]liberal economy. ${ }^{17}$

The use of the breadfruit tree for artistic and organizational works here is a symbol of the commitment of L'Artocarpe to configure a space for discussion and public exchange. As Ferly states, the enclave at L'Artocarpe somehow resuscitates (not symbolically, but factually) the sense of 'collective conspiracy' of former times. If some years ago, she declares, it was common to hear statements such as 'I don't want to show my work because I don't want people to steal my ideas,' now she notices a major interest in artists helping each other, developing cooperative projects, being innovative in their work, following up international currents and exchanging ideas. 
Another interesting feature of L'Artocarpe's engagement has to do with subverting the dependence of artistic practice away from the bonds with the metropolis. L'Artocarpe assists in the preparation of Guadeloupean projects for international exhibitions and biennials. Moreover, the art residency receives artists and specialists with a special focus on the Caribbean, Africa and Latin America. In both activities, local Guadeloupean agents are involved in international, collaborative networks. These fluxes intend to downplay the dependence of the Guadeloupean artworld on France (Ferly, n.d.) There are, however, some limitations, the main one having to do with the fact that the 'alternative global mappings' arising from L'Artocarpe's activity are not necessarily any freer from capitalist, market-oriented determinations than the French context they seek to challenge. Many of the collaborations managed by L'Artocarpe culminate with the participation of Guadeloupean artists in biennials. Although a benefit in terms of international expertise and networking, and a rupture with the primacy of France as the main export destination for Guadeloupean art, can be drawn from those activities, one can question to what extent these initiatives actually challenge Guadeloupean's institutional platforms. I will return to these issues in my conclusion.

\section{Emergence and coordination}

When a political art discourse too often celebrates social disruption at the expense of social coordination, we lose a more complex sense of how art practices contribute to inter-dependent social imagining. (Jackson, 2011, p. 14)

In considering these two projects, we can recognize not only a concern for exploring and eventually criticizing how the Puerto Rican and Guadeloupean material conditions of artistic practice and cultural infrastructures work. There is also an interest in 'producing' practical alternatives to these infrastructures. As we have seen, this interest has to do with engaging with the material conditions of artistic creativity. By eschewing representational notions of identification and transformation, both projects address specific collective needs. Although some of those needs are shared by many alternative art institutions all over the world, in this case they touch urgent issues having to do with the specific predicament of Puerto Rico and Guadeloupe. When examining them, I categorized them as a response to particular problems. I suggested that both BetaLocal and L'Artocarpe aim to formulate - in two radically different ways - operational structures which aim to relieve the consequences of deficiencies emanating from the public sphere. The generative condition of some of the structures I have just discussed leads us to analyze our two projects from standpoint of their institutional functionality.

Consider BetaLocal's 'less artistic' structural activities, such as the articulation of an 'alternative' library in Old San Juan or the organization of potluck dinners to cover the expenses of some of the visitors who cannot afford travel costs. BetaLocal's library is unique on the island. It gathers together a plethora of titles on tactical media, contemporary art and social activism. Moreover, the library has been collecting a wide range of independent publications related to the Puerto Rican art world, such as fanzines, posters and documentation from other artist-managed spaces. With regard to the potlucks, these usually precede a residency in the La Práctica or The Harbor programs. Since they are not linked to any of the project programs, they bring together heterogeneous audiences, ranging from 'people from the art world' to participants in La Iván Illich, area residents and 
international visitors. The charging of an admission fee helps to offset the financing of BetaLocal's fellowship programs. In turn, after developing their residency, BetaLocal's interns often organize another event to generate funding for the next fellowship, residency or lecturer.

It goes without saying that both initiatives have a widely known genealogy. To mention only the most recent and readily identifiable layers of that genealogy, we may consider how the library clearly resembles Thomas Hirschhorn's 'Monuments'. The image of Rirkrit Tiravanija's cooking in museums and biennials comes to mind when considering BetaLocal's potluck dinner, as do, for example, Superflex's fund-raising events. Despite these precedents, it is interesting to focus on how these activities work here. The durational character of both actions detaches both projects from collaborative projects such as Thomas Hirschhorn's monuments or Tiravanija's cooking. Hirschhorn's 'participatory projects' also rely on the gathering of local knowledge and the generation of spaces of coexistence in specific contexts during the time of the exhibition or biennial. The temporality of each project is also contingent upon the general event they are part of. Similarly, the 'locality' of the 'participants' is determined by the artist, and the space of the exchange is dependent on the major structure of a biennial (see Kester, 2011). Concerning the target audiences, in the case of BetaLocal, the public is not 'convened' by the promise of participating in a singular experience designed by high-profile artists. Instead, both the library and the potlucks are imagined as periodical platforms for social interaction. Far from being universal - they share the same difficulties in gathering 'non-artistic' audiences BetaLocal is finding in other occasions - they form part of a platform of activities that reaches (again, with limitations) across artistic and non-artistic spheres. Finally, another difference comes in the form of function. At BetaLocal, it is impossible to detach the configuration of the library and the potlucks as social, supportive activities within the framework of 'more valuable' artistic practices. They are - and they intend to be - part of a totality. Furthermore, they intend to be part of an organizational, functional structure.

Now, can we categorize this functionality as 'institutional'? How 'counter-institutional' are BetaLocal and L'Artocarpe? Indeed, how 'counter-institutional' can collectivism actually be? In the conversations I had with (sympathetic) audiences and with each project's coordinators, they concurred that there was a considerable distance between the activities being developed by BetaLocal and L'Artocarpe and those of museums, universities and other cultural centers. In order to sustain this argument, questions of accessibility, alternativeness and marginality frequently appeared. So did notions of informality, flexibility and participation.

We must be cautious in defining this differentiation, however. To cite one simple reason for this, many of these same qualifiers can be used to characterize the activities of the two major contemporary art museums in San Juan. The Puerto Rican case is not exceptional at all in this sense. Nowadays, cultural institutions have swallowed and incorporated criticism and 'participation' within their own discourse (see Alberro \& Stimson, 2009; Raunig \& Ray, 2009; Welchman, 2006). 'Informality' and flexibility are no longer excluded from the lexicon of even the most traditional art institutions. On the contrary, museums, art centers and biennials have displayed a consummate skill at incorporating both criticism and collaborative and participatory practices within their agendas. As a consequence of this confusion, the claim that cultural institutions fulfill practical social needs is more ubiquitous than ever. As we have stated, nevertheless, this is not always the case. On the contrary, the Caribbean 
artistic medium is a good example of the limitations of artistic audiences in term of race, gender and class.

It would be tempting to configure my two projects within a framework that is 'outside' or external to institutional power, as part of a counter-hegemonic position of resistance. However, I doubt that this opposition between institutional and counter-institutional practices applies to my two case studies. For the examples I have provided seem to be more than oppositional or exodus measures. They are, on the contrary, productive ones. ${ }^{18}$ They present, I suggest, a more ambivalent relationship between transformative action and institutional power. In both initiatives, there is a desire for generating the 'immersive interaction and [a] referential orientation to specific sites of social production' that Kester (2011, p. 37) recognizes in collaborative practices. Similarly, we have seen how L'Artocarpe responded to the lack of platforms for critical dialogue in Guadeloupe by adopting a union-like scheme. Both structures emerged outside of any restricted or preexisting notion of collective identities or groups. Rather, these identities materialized through praxis and action. It is this ability to imagine and perform heterogeneous collective agencies which fuels their operational capacity.

\section{Conclusions}

With regard to the construction of a museum in the (still dependent) space of Réunion, Vergès (2007, p. 455, our translation) recently asked in what way can an institution operating in such a context contribute 'to the emancipation of individuals, that is, to their capacity of imagining new ways of living, of being citizens, of being curious, of creating'. Shifting from museums to artist-managed spaces, this paper aims to reframe questions such as these. To what extent does an artist-managed space frame those questions in a different way? Or, if we wish to consider this issue from a more negative stance: what would be the role - and what would be the nature - of any such institution that fails to achieve those insurgent goals? In this article, I have attempted to extrapolate those general questions to the context of non-autonomous territories in the Caribbean.

The two case studies I have analyzed in this article offer good examples of how infrastructural artistic practice can produce situations in which new kinds of work are made possible. They offer a model of practice not subsumable under innocuous and decorative views of artistic resistance and insurgence opposed to abstract, external (and eternal) powers. Rather, both spaces stand for a kind of cultural experience that directly and practically challenges the dependent, material configuration of Puerto Rico and Guadeloupe, thus proposing alternative organizational responses that should not be understood as merely symbolic, innocuous gestures.

In this article, I have located the activity of L'Artocarpe and BetaLocal within a situation in which the restrictions imposed by a non-autonomous and dependent condition generate new needs and new functions that are only attainable through cooperation and collaboration. Although many of those functions are present in any artistic context, others constitute responses toward the situation of cultural dependence toward metropolitan territories both countries still experience. In the two contexts this article approaches, the side of 'opacity' and 'antagonism' is already taken by individual practices that deem themselves oppositional toward vaguely defined capitalist, (neo)colonial forces. By 
moving beyond representational criteria, cooperative practices can challenge the limitations of such a model on two fronts: first, they are able to address the material conditions of artistic production. Second, they portray an institutional potential, that is, a capacity for generating an alternative framework for action. This potential reacts against what Brian Holmes (2007, p. 58) has referred to as the 'governmentality of failure', a situation in which 'the subject can do no more than contemplate his or her own psychic prison, with a few aesthetic luxuries in compensation'.

Each section of this article has attempted to broach in detail each of these questions. Concerning the first, my main interest has been in outlining how the Puerto Rican and the Guadeloupean artistic infrastructures respond to two different models, although both are influenced by the colonial condition of these territories. I have tried to consider whether my two examples are alternatives, and not reflections, of that state of things. Being unable to counter both countries' political status, these projects have developed the capacity to fill some of the gaps left by other institutions and to thereby generate social processes of interaction, discussion and cooperation. As I have explained, these processes channel heterogeneous agendas and operate with variable audiences, to the extent that they create, in some cases, discomfort and discrepancy (the heterogeneity of the associates of L'Artocarpe and the interaction of the participants of BetaLocal's different initiatives are good examples of this).

My second concern was with the possibility of the project's capacity to not only address but also transform the social conditions of artistic activity. My interest here lay in exploring the potential of organizational models such as these, revealing how the functioning of such initiatives can not only alter questions of appreciation, valorization and categorization, but also generate alternative institutional dynamics and operational platforms. As an example, I have focused on some of BetaLocal's collaborative initiatives. Far from being unique, these initiatives have had the signature of some recognized artists. It is significant how BetaLocal and L'Artocarpe, as well as other Caribbean spaces of this kind, have come to be positively valued both within and beyond their local contexts. Sometimes this recognition surpasses that of public and private museums. In this sense, one can think of some of the projects I mentioned earlier on, such as CCA7, Galvanize and Alice Yard in Trinidad, which have worked as pivotal regional centers. The Trinidadian examples constitute ongoing experiments that seek to transform the conditions under which art is produced and discussed. They are even more significant due to the anemic condition of public or private artistic infrastructures in that country. I have tried to demonstrate how Caribbean artist-managed projects have been pivotal in developing alternative engagements with local reality.

I have also sought to understand whether the creative potential I have described can be extrapolated to broader latitudes and situations. Are my two examples exceptions or indicators of a global state of things? I have tried to show how a deeper analysis of collective initiatives taking place in similar contexts will not only incorporate forgotten or neglected examples into existing canons and art histories. More clearly, in approaching them, my interest has not been to 'complete' global mappings of collaborative practices. On the contrary, I maintain that the dependent condition of my territories of analysis reveals itself especially eloquently in terms of the potential, but also some of the main debates on organizational and socially engaged art practice on issues such as autonomy, functionality, labor, cohesion, productivity, visibility, expertise and recognition. 
The activity of our two projects is dependent upon such values as duration, flexibility, horizontality, innovation, exchange process and connectivity. Those elements can be seen as functional values, yet, as we have seen, they are also behind aesthetic decisions. If both spaces share an orientation toward collective praxis, they seem to be prone to pursue opposing paths in terms of their understanding of artistic practice. Whereas BetaLocal aims for a deregulation and de-specialization of cultural interaction and creativity, L'Artocarpe has become a 'herald of the contemporary'. In any case, we have seen how some of their activities ultimately converge toward the same system they seek to challenge. Examples of this can be found in L'Artocarpe's turn toward the 'contemporary', in its linking artistic advancement and international participation; or in BetaLocal's inability to withdraw from the 'exclusivity' of art audiences. To some extent, the limitations of both projects are particularly eloquent of the most limiting features of the non-autonomous cultural milieu from which they arise. If we had to criticize them only for these elements, then, we could say that collaboration works as an appealing yet innocuous and tolerable singularity, unable to generate a significant shift from the inherited non-autonomous cultural dynamics present in both territories.

I have attempted to show that such a valorization is incomplete. There is something else. We have seen how both projects create and consolidate alternative social bonds and platforms for action. These undercut the spatial imagination in play in both scenarios. If we consider the same examples from this vantage point, we can see how L'Artocarpe's structure consolidates an open public sphere that criss-crosses the colonial bonds of Guadeloupe by establishing connections with other art scenarios. This sphere is not the 'local side-effect' of the project's international activity. Rather, both levels are intertwined. Something similar can be said of BetaLocal. Its interest in 'de-educating' the over-specialized, over-exposed and highly sophisticated Puerto Rican artistic milieu situates its sphere of activity between that of artist-managed spaces and non-profit organizations. It is the porosity across audiences, programs and spatial levels that fuels BetaLocal's most innovative outcomes. In sum, both L'Artocarpe and BetaLocal act as organizational-yet-flexible structures, thereby aiming to expose the artistic and social structures operating both in Puerto Rico and in Guadeloupe, and to break with the precariousness dominating the artistic scenarios in which they operate. Arising from two very different contexts, which, nevertheless, share a non-autonomous condition, the two projects that I have analyzed here offer interesting examples of collaborative agency and its ability to trigger an alternative social imagination. They are fueling tangible transformations that touch upon organizational and structural conditions of artistic practice, while also relying on collective, local agency as a driving force for change.

\section{Notes}

1. Those issues have centered the art criticism from and about the region in the last decades. See Poupeye (1998), Stephens (2013), Thompson (2006) and Wainwright (2011). I have engaged this debate in Garrido Castellano (2014, in press). Although those insights have been crucial in order to dismount inherited visual and cognitive apparatuses of misrepresentation and commoditization of the Caribbean region, making emphasis in the multiple ways in which Caribbean creators have striven to define and assert counter-representation, less attention has been paid at organizational and infrastructural practices. Because of that, without forgetting the debates on Caribbean art, I will try to delve into those practices more in detail through long-term, practice-based, collective artistic initiatives. 
2. The Caribbean currently has 14 territories that are politically linked, yet with different status, to France, Great Britain, Netherlands and the United States. The literature on the colonial and postcolonial predicament of the Caribbean region is extremely vast. Whereas this condition will be central to my argument in this article, I will not try to define what colonialism is or how does it impact Caribbean cultural practices. Instead, I will try to refer to situations in which that condition has a specific impact on artistic practices and actions.

3. The Taller Alacrán will be a pivotal platform of social and political resistance through graphic arts in the Puerto Rican context of the 1960s. It also inaugurates the romance between independent art centers and the neighborhood of Santurce in San Juan (see Díaz-Royo, 2008; Hermandad de Artistas Gráficos de Puerto Rico (ed.), 1998).

4. CCA7 was a Prince Klaus Awarded project created in 1997 by Charlotte Elias, which included the collaboration of Christopher Cozier, Peter Doig and Chris Ofili. Alice Yard, directed by Cozier, Sean Michaels and Nicholas Laughlin, was created in 2006 as a collaborative space located in downtown Port of Spain. It continues to be one of the most highly esteemed artist-managed projects in the entire Caribbean. Galvanize, organized by Mario Lewis and Steve Ouditt, was more exhibition-oriented and had a shorter life.

5. Created in 2011, Fresh Milk offers a platform for critical and creative dialogue, an artistic residency and a contact point between contemporary art and the local population of Barbados.

6. LASA (Laboratorio Artístico de San Agustín) is an art space located at the periphery of Havana, focusing on nurturing a territory traditionally isolated from the cultural effervescence of the Cuban capital. Espacio Aglutinador was the first private art space in Havana, founded in the 1990s by Sandra Ceballos and Ezequiel Suárez. The Cátedra de Arte y Conducta was Tania Bruguera's pedagogic project developed between 2002 and 2009. Finally, DUPP (Desde una Pragmática Pedagógica) is a public intervention collective organized also in the 2000s by the Cuban artist and teacher René Francisco Rodríguez (see Weiss, 2011).

7. Created in 2006 by Tirzo Martha, in the space of a psychiatric institution, the IBB encourages collaboration with local communities in Curação, including the clinic patients. It also offers a residency and an educational program.

8. Santiago Muñoz has developed a strong body of filmic work dealing with the legacy of coloniality in the island and exploring the genealogies of Puerto Rican and American anarchist and radical imaginaries. For an exhaustive view of her work, see Garrido Castellano (2016). On his behalf, 'Tony' Cruz has focused on the relation between informational and spatial devices and power. The focus of this article on the collective dynamics developed around BetaLocal does not imply any depreciation of its founders' careers as solo artist.

9. This, however, does not always occur, at least not in the same terms. In our conversations in San Juan in 2012, both Santiago Muñoz and Tony Cruz noted how La Práctica ended up producing a far too individual, 'theory-based' experience, while only vaguely generating the cooperative results it expected to achieve.

10. See http://thepublicschool.org/.

11. Email conversation with José 'Tony' Cruz, Beatriz Santiago and Pablo Guardiola, March 2015. All three agree that engaging regularly with non-artistic audiences is perhaps the major challenge they have faced since the creation of BetaLocal.

12. We should not forget that the funding for that participation comes from an organization dependent on the French Ministry of Culture.

13. Especially active are the Museo de Arte de Puerto Rico (MAPR) and the Museo de Arte Contemporáneo de Puerto Rico (MACPR), both located in Santurce. The former developed a program in the 2000s aimed at helping Puerto Rican artists with questions of creativity and exhibition (http://mapr.org/es/museo/proa). The latter carries out site-specific and collaborative works, provides experimental space for workshops and artist studios, and organizes educational programs for different communities.

14. Personal interview with Beatriz Santiago and José 'Tony' Cruz. San Juan, June 2012.

15. In fact, the category of 'Art d'Outre Mer' has served as organizing idea for a series of exhibitions gathering the artistic production of former (and present) colonial territories. The 
Latitudes series, curated by Regine Cuzin between 2002 and 2007, or OMA. Outre-Mer Art Contemporain (2011) are good examples of this tendency.

16. As in the cases of Santiago and Cruz, the artistic work of Joëlle Ferly also responds directly to those issues. In 2009, Ferly was asked to contribute to a collective exhibition held at the Foundation Clément. The Fondation is the major art space in the Francophone Caribbean, a vast exhibitional space located in Martinique, in the space of a former plantation. In order to contribute to the exhibition, Ferly declared herself on strike and started serving the catering to the audience of the Fondation, widely segmented in terms of class and race. The action took place in the context of the general strike that mobilized the Francophone Antilles in 2009 in demand of better salaries for low-income workers and a decrease of the cost of basic commodities, and summarizes well Ferly's interest in engaging critically with issues of her local context.

17. http://www.artocarpe.net/Arto-Mission-Statement_r14.html.

18. Raunig and Ray (2009, p. 20) refer to these measures as 'Instituent Practice'. For them, the concept of 'instituent practices' marks the site of a productive tension between a new articulation of critique and the attempt to arrive at a notion of 'instituting' after traditional understandings of institutions have begun to break down and mutate.

\section{Acknowledgements}

The research developed here was produced over several long-term research stays in Puerto Rico (2010, 2012, 2015), Guadeloupe (2011) and the United States (Lilly Library, Duke University, 2013; NYU Bobst Library, New York University, 2015). I would like to acknowledge the collaboration of Joëlle Ferly in Guadeloupe, Laura Bravo López, Beatriz Santiago Muñoz, Pablo Guardiola and José 'Tony' Cruz in Puerto Rico, and Gregory Sholette in the United States. The images included in this article are courtesy of Joëlle Ferly and Beatriz Santiago Muñoz.

\section{Disclosure statement}

No potential conflict of interest was reported by the author.

\section{Funding}

This work was supported by the Fundação para a Ciência e a Tecnologia (FCT) [Grant SFRH/BDP/ 92492/2013].

\section{References}

Alberro, A., \& Stimson, B. (Eds.). (2009). Institutional critique: An anthology of artists' writings. Cambridge: MIT Press.

Bailey, D., Cummins, A., Lapp, A., \& Thompson, A. (Eds.). (2012). Curating in the Caribbean. Berlin: The Green Box.

Bourriaud, N. (2002). Relational aesthetics. Paris: Les presses du reel.

Cozier, C. (2011). Notes on wrestling with the image. In C. Cozier \& T. Flores (Eds.), Wrestling with the image: Caribbean interventions (pp. 6-15). Washington, DC: The World Bank.

Craven, D. (2006). Art and revolution in Latin America 1910-1990. New Haven, CT: Yale University Press.

Cullen, D., \& Fuentes, E. (Eds.). (2012). Caribbean: Crossroads of the world. New York, NY: Yale University Press, El Museo del Barrio.

Díaz-Royo, A. (2008). Martorell: La aventura de la creación. San Juan: Universidad de Puerto Rico.

Fall, N., \& Pivin, J. L. (Eds.). (2002). An anthology of African art: The twentieth century. New York, NY: D.A.P., Revue Noire Editions. 
Ferly, J. (n.d.). L'Artocarpe, contemporary art: Getting away from the French Enclave. Unpublished manuscript.

Flores, J. (2010). The diaspora strikes back. Caribeño tales of learning and turning. New York, NY: Routledge.

Garrido Castellano, C. (2014). Conceptual materialism. Installation art and the dismantling of Caribbean historicism. Third Text, 28(2), 149-162.

Garrido Castellano, C. (2016). Imperial spatio-temporal disarrangements. Beatriz Santiago Muñoz's Performative Documentary and the Emancipative Unseen. Centro. Journal of the Center for Puerto Rican Studies, 28(1), 60-92.

Garrido Castellano, C. (in press). Rethinking the "transnational" Caribbean curatorial: Caribe insular: Exclusión, Fragmentación y Paraíso's politics of space. Small Axe: A Caribbean Journal of Criticism.

Holmes, B. (2007). Extradisciplinary investigations: Towards a new critique of institutions. Retrieved from http://eipcp.net/transversal/0106/holmes/en

Jackson, S. (2011). Social works. Performing arts, supporting publics. London: Routledge.

Kester, G. (2011). The one and the many: Contemporary collaborative art in a global context. Durham, NC: Duke University Press.

L'Étang, G. (Coord.) (2007). La peinture en Martinique. Fort-de-France: Conseil Régional de Martinique, Hervé Chopin Éditions.

Mosquera, G. (Ed.). (1996). Beyond the fantastic. Contemporary art criticism from Latin America. London: InIVA.

Poupeye, V. (1998). Caribbean art. London: Thames \& Hudson.

Raunig, G., \& Ray, G. (Eds.). (2009). Art and contemporary critical practice: Reinventing institutional critique. London: MayFly Books.

Segarra, A. (2012). Un panorama de alternativas en diálogo desde Puerto Rico. Papeles de Cultura Contemporánea, 16, 46-66.

Stephens, M. (2013). What is an Island? Caribbean studies and the contemporary visual artist. Small Axe: A Caribbean Journal of Criticism, 17, 8-26.

Stimson, B., \& Sholette, G. (Eds.). (2007). Collectivism after modernism: The art of social imagination after 1945. Minneapolis: University of Minnesota Press.

Thompson, K. (2006). An eye for the tropics. Tourism, photography, and framing the picturesque. Durham, NC: Duke University Press.

Thompson, N. (Ed.). (2012). Living as form. Socially-Engaged art from 1991-2011. Cambridge: MIT Press and Creative Time.

Tiburce, F. (1994). La voie du Fwomajé. L'art du dedans. Fort-de-France: Association Fwomajé.

Vergès, F. (2007). Le musée postcolonial: un musée sans objets. In N. Blancel, F. Bernault, P. Blanchard, \& V. Amiraux (Eds.), Ruptures postcoloniales. Les nouveaux visages de la société française (pp. 455480). Paris: La Découverte.

Wainwright, L. (2011). Timed out. Art and the transnational Caribbean. Manchester: Manchester University Press.

Weiss, R. (2011). To and from Utopia in the new Cuban art. Minneapolis: University of Minnesota Press.

Welchman, J. C. (Ed.). (2006). Institutional critique and after. Zurich: JRP/Ringier. 